\title{
The Future of Freshwater in Shatt Al- Arab River (Southern Iraq)
}

\author{
Safaa A. R. Al-Asadi ${ }^{1}$ \\ ${ }^{1}$ Department of Geography, Collage of Education, University of Basrah, Basrah- Iraq \\ Correspondence: Safaa A. R. Al-Asadi, Department of Geography, Collage of Education, University of Basrah, \\ Basrah- Iraq. E-mail: alasadysafaa74@gmail.com \\ Received: May 6, 2017 \\ Accepted: May 16, 2017 \\ Online Published: May 27, 2017 \\ doi:10.5539/jgg.v9n2p24 \\ URL: https://doi.org/10.5539/jgg.v9n2p24
}

\begin{abstract}
This study uses data from the current rate of population growth, agricultural development and effects of climate change to estimate the future of water demand and the amount of available water in the Shatt Al-Arab River basin. The Shatt Al-Arab River will be facing a freshwater deficit as a result of the decrease of water received from its tributaries. Currently, the river receives freshwater from the Tigris only, as a result to dam construction projects on the tributaries remaining. In 2040, it is expected that the freshwater from the Tigris will not be available to the Shatt Al-Arab; therefore the intrusion of seawater into the river will increase. This may cause a gradual change of water quality in the river from freshwater to seawater. When the Shatt Al-Arab River loses freshwater from all its tributaries the seawater will progress further from Persian Gulf towards the upstream.
\end{abstract}

Keywords: Water deficit, water demand, water quality, seawater intrusion, Tigris and Euphrates, Shatt Al-Arab

\section{Introduction}

In full Shatt Al-Arab River (SAR) receives freshwater from four main tributaries, which are; The Tigris, Euphrates, Karkheh and Karun Rivers. Despite the fact that these tributaries originate in the mountains of Turkey and Iran, Syria and Iraq share the waters of this basin. Therefore, the SARB is considered as a transboundary river basin.

The Basin faces accelerated growth of irrigated area, population and dam construction as well as climate warming (Jones et al., 2008; Bozkurt \& Sen, 2013; Issa et al., 2014). Moreover, in this region water withdrawal are very high, although the renewal water rate is low because of dominating arid climate (El-Fadel et al., 2012). There is no doubt that the increasing water demand within watersheds has the potential to greatly impact the amount of available water flow in their tributaries. Water shortages are affecting the human welfare, economic activity, and political stability (Jones et al., 2008), so, predict the future situation of water is an urgent goal.

Due to the scarcity of other water resources as a result of the arid and semiarid climates, SAR has been considered as the main water resource in Basrah go vernorate. The freshwater of the river also plays an important role in the health of the northern the Persian Gulf ecosystem (Al-Yamani, 2008; UN-ESCWA, 2013). Future predictions suggest increasing severe shortages of the water resources within the region (UNWWAP, 2009; Droogers et al., 2012; Al-Ansari, 2013; Abdullah, 2016). Therefore, the expected decline of freshwater discharge in the SAR will severely affect the water quality as a result of the Gulf's seawater intrusion into that river.

The main objectives of this study are (1) to predict the future of freshwater quantity in the Shatt Al- Arab channel based on the amount of water received from the River's tributaries. (2) to study the spatial and temporal variation in concentration of the total dissolved solid (TDS) along the river, as an indicator on the marine waters intrusion from Persian Gulf into the river, and to determine the extent of change in the river's water quality from freshwater to seawater.

\section{Method}

\subsection{General Description of the River and Its Basin}

The SAR is created by the confluence of the twin rivers the Tigris and the Euphrates in the city of Qurna in southern Iraq about $160 \mathrm{Km}$ north of Persian Gulf. It extends to the southwest for around $120 \mathrm{~km}$ within Iraqi lands and $80 \mathrm{~km}$ the river constitutes the Iraqi-Iranian boundaries, before running into the Gulf (Figure 1). The river's total length is about $200 \mathrm{~km}$, its width ranges between $330 \mathrm{~m}$ in Qurna to $1250 \mathrm{~m}$ in the estuary and its depth varies from 8.5-24 m(Al-Asdi, 2016). 


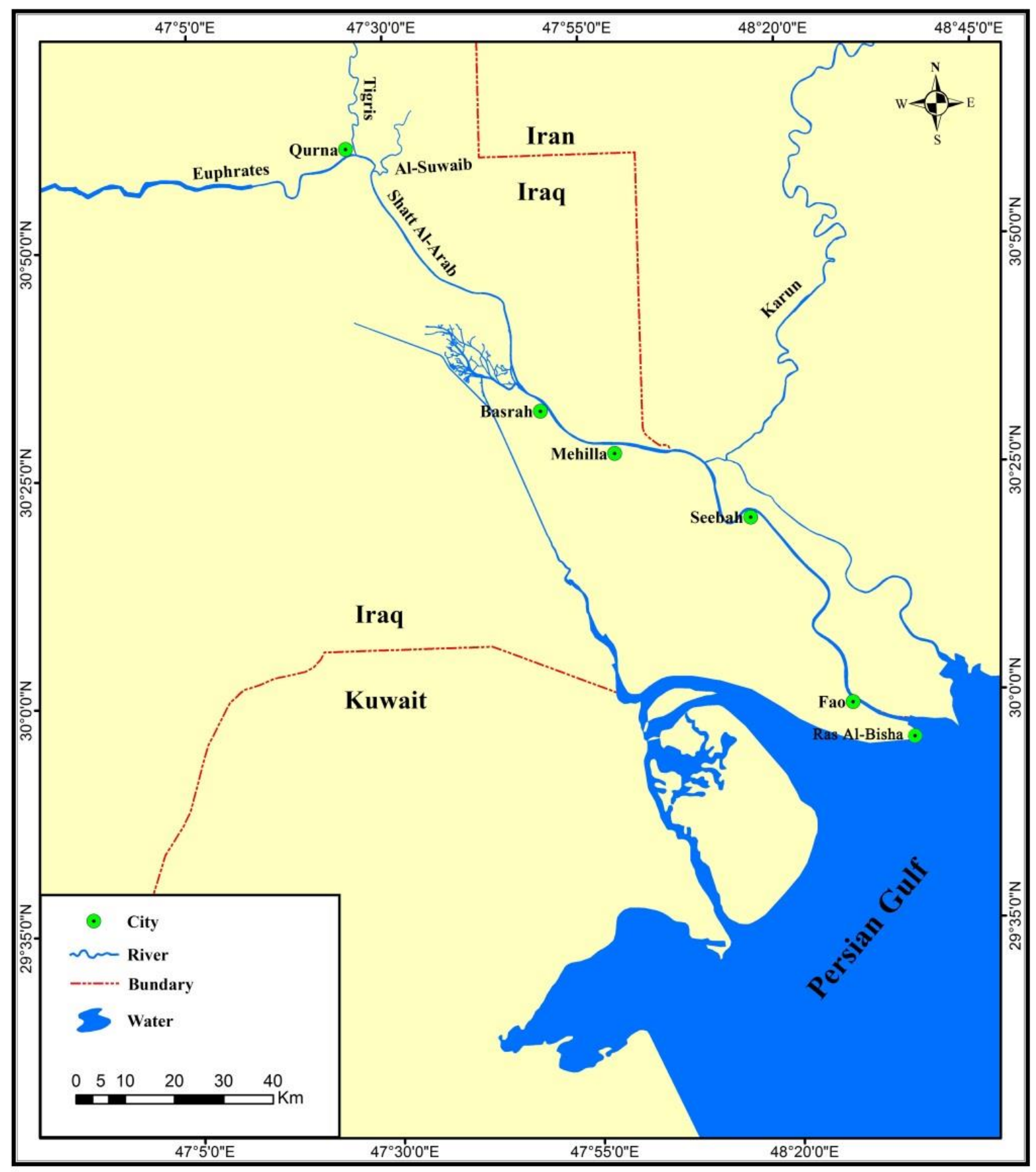

Figure 1. Map of Shatt Al-Arab River (Modified from National Geography Maps in ArcGIS)

In addition to the Tigris and the Euphrates, there are several sub-tributaries disemboguing in the SAR, most importantly the Karkheh and the Karun Rivers. The Karkheh River contributes to feeding Hawizhe marshes, whose water eventually flow into the main river via joining Al-Suwaib River on the eastern bank of the SAR about $5 \mathrm{~km}$ south of the Tigris- Euphrates confluence. The Karun River joins the eastern bank of that river about $72 \mathrm{~km}$ north of Persian Gulf.

The Shatt Al-Arab River basin (SARB) is considered a transboundary basin, shared by five neighboring countries to Iraq (Turkey, Iran, Syria, Saudi Arabia and Jordan, in addition to Iraq) (Figure 2). It is total surface area is around $938,305 \mathrm{~km}^{2}, 53.16 \%$ of which lies in Iraq (Table 1). Therefore, the SARB is the largest basin in southwest Asia. The total water potential of that basin is around $106.02 \mathrm{~km}^{3} / \mathrm{yr}$. Iraq provides $15.81 \%$ of the total water volume of the basin via feeding the Tigris River in about $16.77 \mathrm{~km}^{3} / \mathrm{yr}$. 


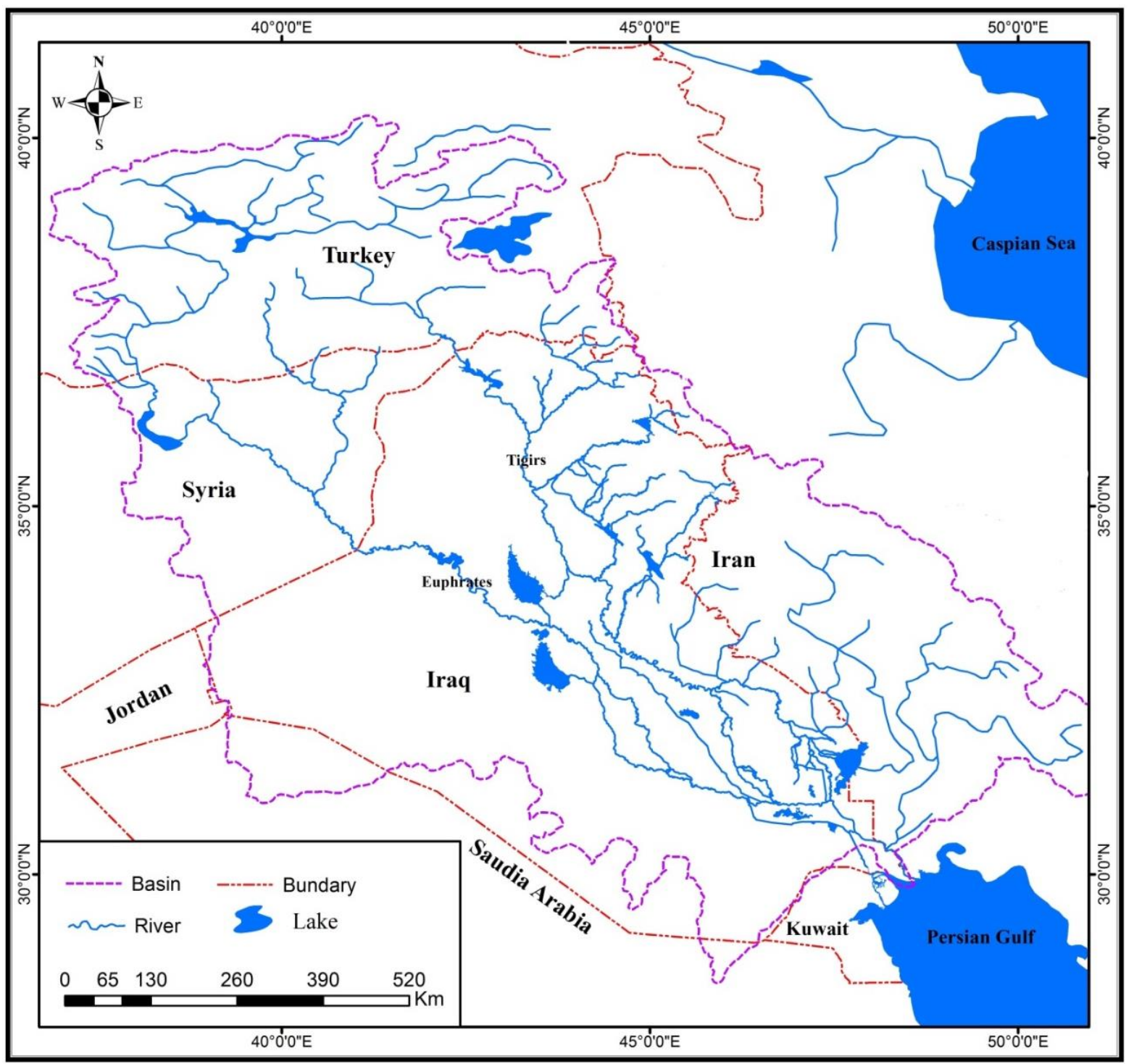

Figure 2. Map of Shatt Al-Arab River Basin (UN-ESCWA, 2013)

The Tigris and the Euphrates are the two important and greatest rivers of the basin. They contribute to about $76.89 \%$ of the total flow, because of the twin rivers produce a mean annual flow of $43.00 \mathrm{~km}^{3} / \mathrm{yr}$ and 32.72 $\mathrm{km}^{3} / \mathrm{yr}$, with a total length of $1862 \mathrm{~km}$ and $3000 \mathrm{~km}$ respectively (Table 1). The Tigris and Euphrates Rivers originate from the same region in eastern highlands of Turkey about $30 \mathrm{~km}$ from each other. The Karkheh and the Karun are the sub-rivers of the SARB, their flow reduces to $24.5 \mathrm{~km}^{3} / \mathrm{yr}$ and $5.8 \mathrm{~km}^{3} / \mathrm{yr}$ respectively. Therefore, these two rivers originate in Iran, which contribute to about $28.58 \%$ of the total flow in the SARB.

\subsection{Hydrological Characteristics of the SAR}

The hydrological regime of the SAR depends mainly on the discharge amount of freshwater from the four tributaries of the river and the progression of seawater by the tides from the Gulf. Declining freshwater flow into that river increases the impact of seawater (Al-Asadi, 2016). The mean annual discharge of the SAR is around $37.5 \mathrm{~km}^{3} / \mathrm{yr}$. The Tigris River contribute to around $14.3 \mathrm{~km}^{3}(38.1 \%)$, and $11.4 \mathrm{~km}^{3}(30.4 \%)$ from the Euphrates River, while the Karun River $8.5 \mathrm{~km}^{3}(22.7 \%)$ and the Karkheh River $3.3 \mathrm{~km}^{3}$ (8.8\%) (Ministry of irrigation, 1979). This freshwater discharge varies seasonally according to its tributaries contribution. As a result to huge discharge of the Shatt Al-Arab, the chemical effects of seawater on the area nearby the river's estuary are limited.

The tidal regime in the river is a mixture of the diurnal and semi-diurnal types with dominant semi-diurnal (Al-Mahdi \& Salman, 1997). 
Table 1. Riparian countries contribution to the SARB

\begin{tabular}{llllllll}
\hline River & Country & $\begin{array}{l}\text { Basin area } \\
\mathrm{km}^{2}\end{array}$ & $\%$ & $\begin{array}{l}\text { Discharge } \\
\mathrm{km}^{3}\end{array}$ & $\%$ & $\begin{array}{l}\text { Length } \\
\mathrm{km}\end{array}$ & $\%$ \\
\hline Tigris & Turkey & 45,000 & 12.00 & 21.93 & $51^{3}$ & 400 & 21 \\
& Iraq & 292,000 & 77.86 & 16.77 & $39^{3}$ & 1418 & 77 \\
& Iran & 37,000 & 9.87 & 4.30 & $10^{3}$ & 0 & 0.0 \\
& Syria & 1,000 & 0.27 & 0.00 & 0 & 44 & 2 \\
& Total & $375,000^{1}$ & 100 & $43.00^{2}$ & 100 & $1862^{1}$ & 100 \\
Euphrates & Turkey & 123,200 & 28.00 & 29.12 & $89^{3}$ & 1230 & 41 \\
& Iraq & 206,800 & 47.00 & 0.00 & 0 & 1060 & 35 \\
& Syria & 96,800 & 22.00 & 3.60 & $11^{3}$ & 710 & 24 \\
& Saudi & 13,068 & 2.97 & 0.00 & 0 & 0 & 0 \\
& Jordan & 132 & 0.03 & 0.00 & 0 & 0 & 0 \\
& Total & $440,000^{5}$ & 100 & $32.72^{2}$ & 100 & $3000^{3}$ & 100 \\
Karkheh $^{4}$ & Iran & 51,325 & 100.0 & 5.8 & 100 & 964 & 100 \\
Karun $^{5}$ & Iran & 71,980 & 100.0 & 24.5 & 100 & 867 & 100 \\
Shatt Al-Arab & Turkey & 168,200 & 17.93 & 51.05 & 48.15 & - & - \\
& Iraq & 498,800 & 53.16 & 16.77 & 15.81 & $120+80$ & 100 \\
& Iran & 160,305 & 17.08 & 34.60 & 32.64 & 80 & 40 \\
& Syria & 97,800 & 10.42 & 3.60 & 3.40 & - & - \\
& Saudi & 13,068 & 1.40 & 0.00 & - & - & - \\
& Jordan & 132 & 0.01 & 0.00 & - & - & - \\
& Total & 938,305 & 100 & 106.02 & 100 & 200 & - \\
\hline
\end{tabular}

Sources:

1 (UNEP, 2001, Biedler, 2004)

2 (Kangarani , 2006; Al-Ansari et al, 2014)

3 (FAO, 2009; Biedler, 2004 )

4 (Marjanizadeh et al, 2009)

5 (UN-ESCWA, 2013)

\subsection{Data Collection}

The data used in this study are collected from different resources, such as the population and agriculture of the SARB. These data are used to estimate the water demand. The population size over the basin's countries (Turkey, Iran, Syria and Iraq) in 2010 was adopted from UN-ESCWA(2013), and the rate of population growth during the years 2000 to 2005 was prepared by using tables of the United Nations (2001). A total agriculture area and irrigated area in 2000 within the main tributaries of the basin (the Tigris, Euphrates, Karkheh and Karun Rivers) are extracted from different resources (FAO, 2009; Patrick, 2004; Marjanizadeh et al, 2009; sadeghian et al, 2003; Jaradat, 2002). Agriculture growth rate data during the years 1991- 2000 was provided by Belloumi \& Matoussi (2009). Climate change data is important to the potential available water and evaporation losses, these data are extracted from Milly et al. (2005), UNWWAP (2009), Republic of Turkey (2009), Terink et al. (2013) and Bozkurt \& Sen (2013). Annual water discharge of the main tributaries was collected from Kangarani (2006), Marjanizadeh et al. (2009), UN-ESCWA (2013) and Al-Ansari et al. (2014). Total dissolved solid (TDS) concentration was used in this study to investigate the changes in river water quality during the years 1977- 1978 as a base year to 2010- 2011 based on data availability. The data concerning TDS were compiled from four important sites along the river from city center (Basrah) to the Fao city (estuary area) (Ministry of Water Resources, 1979; Hussin et al., 1991; Al-Asadi et al., 2015).

The prediction for the future size of the population, irrigated areas, evaporation values and tributaries water discharge are obtained by applying the following formula in Microsoft Excel 2010 software (Mavron \& Phillips, 2000):

Where:

$$
P t=P 0(1+r) t
$$

Pt denotes the size of the variables at time t. 
P0 denotes the initial size of the variables.

$r$ denotes the Annual Growth rate of the variable.

It should be noted that there are several economic, cultural and technical factors which contribute to the change of growth rates. However, these rates are assumed to remain constant over the prediction decades. The end of the prediction is defined as the year 2040 to coincide with the completion of the operations of the Southeastern Anatolia Project (GAP) in Turkey is expected to last the year 2030 or even 2040 (USAWC, 2001).

The water balance of the main tributaries for four decades (2000-2040) is predicted based on data that include the available water and the expected future water demand for agricultural and domestic use that covers about $95 \%$ of the total water withdrawal across the basin (Kangarani, 2006), taking into account the decrease of annual water discharge and increase of the evaporation losses from lakes surface due to climate changes. The seepage losses from water bodies and industrial withdrawals are excluded from this study due to the fact that seepage may be insignificant as a result to dominants of silt and clay sediments across the basin (Aqrawi, 1995), and inherent difficulty in determining industrial usage. The result of water balance is used to expect freshwater that could reach the Shatt Al-Arab channel. Water balances are computed with the assumption the growth rate of water utilization is constant for the study horizon. The water balance is computed as (Patrick, 2004):

$$
\text { Water Balance }(k m 3 / y r)=\text { Supply }- \text { Demand }
$$

Where:

Supply = annual water discharge $\left(\mathrm{km}^{3} / \mathrm{yr}\right)$

Demand $=$ annual water withdrawn $\left(\mathrm{km}^{3} / \mathrm{yr}\right)$.

\section{Results}

\subsection{Factors Affecting Runoff within the SARB}

\subsubsection{Population Growth in the SARB}

Population growth leads to stress on water resources, due to the increase of the demands for freshwater, as well as the contamination events associated with land uses. Moreover, distribution of population within the region also plays a major role in the pressure on water resources available (Abughlelesha \& Lateh, 2013). Humans already utilized half of the available runoff, either by consumption and agriculture or indirectly in the form of pollution (Postel, 2000).

Census estimations in the SARB shows that the population was 52.41 million people in 2010 (Table 2), more than half of the basin's population (28.60 million, $54.57 \%$ of the total) live in Iraq. Of these, $64.33 \%$ (18.40 million) live in Tigris River and 35.67\% (10.20 million) live in Euphrates River. The mean of water consumption for domestic purposes was 250-350 liters per capita per day.

The annual population growth rate is $1.3 \%$ in Turkey, actual population growth is $1.4 \%$ in Iran, and with an annual demographic growth estimated at $2.5 \%$ in Syria (Table 2). Iraq has the highest rate of population growth among basin's countries; growing at a pace of 2.7\% annually in 2000-2005. Population growth is a direct determinant factor of increases in water demand for domestic uses. So the water demand for domestic uses in the SARB is continuously increasing, especially in Syria and Iraq due to the increase of population.

\subsubsection{Agricultural Development Sector on the SARB}

Turkey is engaged in utilizing both the Tigris and the Euphrates Rivers by the Southeastern Anatolia Project whose contents irrigate around 9,100,000 hectares (ha) along the Euphrates basin and 540,000 ha along the Tigris basin (Table 2). Syria Plans to irrigate around 640,000 ha in the Euphrates River valley, and although it has only one bank of the Tigris River, it Plans to irrigate range from 150,000 to 372,000 ha (Haddad et al, 2013). The Iraqi government decides to irrigate an area of about 3,305,000 ha, 2,200,000 ha are in the Tigris River, $1,000,000$ ha in the Euphrates River, in addition to 105,000 ha in the SAR (Jaradat, 2002).

The total planned area to be irrigated is around 600,000 ha in the Karkheh River basin. The Iranian government planned to provide irrigation water for an ultimate development irrigated area of 480,000 ha in the Karun River. With irrigated land de velopment, the water demand is increasing. Irrigation water needs to vary according to human and natural factors in the countries of the river basin. For Turkey, Iran and Syria the annual irrigation water requirement ranges from $10,000 \mathrm{~m}^{3} /$ ha to $12,000 \mathrm{~m}^{3} / \mathrm{ha}$, and rise in Iraq between $13,000 \mathrm{~m}^{3} / \mathrm{ha}$ to 15,000 $\mathrm{m}^{3} /$ ha (Table 2). 
Table 2. Population and irrigated area water demand within countries of SARB

\begin{tabular}{|c|c|c|c|c|c|c|c|c|}
\hline Country & River basin & $\begin{array}{l}\text { P(MP) } \\
2010^{1}\end{array}$ & $\begin{array}{l}\text { WD } \\
(\mathrm{L} / \mathrm{P})\end{array}$ & $\begin{array}{l}\text { PGR }^{2} \\
00-2005\end{array}$ & $\begin{array}{l}\text { TAA } \\
\text { (Mha) }\end{array}$ & $\begin{array}{l}\text { IA (ha) } \\
2000\end{array}$ & $\begin{array}{l}\mathrm{WD}^{8} \\
\left(\mathrm{M}^{3} / \mathrm{ha}\right)\end{array}$ & $\begin{array}{l}\text { AGR }^{9} \\
91-2000\end{array}$ \\
\hline \multirow{3}{*}{ Turkey } & Tigris & 3.47 & 250 & 1.3 & $0.54^{3}$ & 57,000 & $10,000-$ & $5.7 \% *$ \\
\hline & Euphrates & 7.15 & & & $0.91^{3}$ & 103,000 & 12,000 & \\
\hline & Total/mean & 10.62 & & & 1.45 & 409,655 & 11,000 & \\
\hline \multirow[t]{3}{*}{ Iran } & Karkheh & 4.00 & 250 & 1.4 & $0.60^{5}$ & 93,900 & $10,000-$ & $2.2 \%$ \\
\hline & Karun & 3.50 & & & $0.48^{6}$ & 280,000 & 12,000 & \\
\hline & Total/mean & 7.50 & & & 1.08 & 550,000 & 11,000 & \\
\hline Syria & Euphrates & 5.69 & 350 & 2.5 & $0.64^{4}$ & 240,000 & $\begin{array}{l}10,000- \\
12,000\end{array}$ & $2.6 \%$ \\
\hline \multirow[t]{3}{*}{ Iraq } & Tigris & 18.40 & 350 & 2.7 & $2.20^{7}$ & $1,166,880$ & $13,000-$ & $0.95 \%$ \\
\hline & Euphrates & 10.20 & & & $1.00^{7}$ & 549,120 & 15,000 & \\
\hline & Total/mean & 28.60 & & & 3.20 & $1,716,00$ & 14,000 & \\
\hline
\end{tabular}

Note. P(MP): population (Million people); WD (L/P): water demand (liter/ people); PGR: Population growth rate ; TAA (Mha): Total agriculture area (million hectares); IA: Irrigated area; AGR: Agriculture growth rate.

* Calculated of present study.

Sources:

1 (UN-ESCWA, 2013)

2 (UN, 2001)

3 (FAO, 2009)

4 (Patrick, 2004)

5 (Marjanizadeh et al, 2009)

6 (sadeghian et al, 2003)

7 (Jaradat, 2002)

8 (Beaumont, 1998).

9 (Belloumi \&Matoussi, 2009)

\subsubsection{Hydrological Projects on the SARB}

The freshwater in the SAR and hydrological regime have been intensively affected by the development of dam constructions in the countries of the river basin.

Iraq was the first to start utilizing water of the Rivers by constructing irrigation and flood control systems. The first hydraulic projects were Hindiyah barrage in 1918 on the Euphrates River, and Al Kut barrage in 1939 on the Tigris River, the total storage capacity of the reservoirs was around $144.46 \mathrm{~km}^{3}$ (Table 3). In 1962, Iran completed Dez dam on the Karun River, the overall volume of water in the reservoirs in Iran was around 18.35 $\mathrm{km}^{3}$. In 1970, Turkey started to utilize the water of the Tigris and Euphrates Rivers by the Southeastern Anatolia Project (Guneydogu Anadolu Projesi) otherwise known as GAP. The project includes 13 sub-projects, seven of which are on the Euphrates River and six on the Tigris. The total capacity storage is around $105 \mathrm{~km}^{3}$. Syria built three main dams constructed on the Euphrates River with a total storage capacity of $13.69 \mathrm{~km}^{3}$. Tabaka dam is an important water irrigation project, which was completed in 1975.

\subsubsection{Climate Change in the SARB}

The flow of tributaries of the Basin depends mainly on winter rains and spring snowmelt in the Turkish and Iranian mountains. The flow is also influenced by the evaporation process in Syria and Iraq. Therefore, the climate conditions are dominant factors which determine the flow amount within the catchment area. Though the SARB lies in a transitional zone between humid Continental in Turkey and Iran, and semi-arid to arid of Syria and Iraq, the headwaters of tributaries has a sub-tropical Mediterranean climate with cold, wet winters and hot dry summers. The average monthly temperature over the river basin ranges between $6{ }^{\circ} \mathrm{C}$ in January to $34{ }^{\circ} \mathrm{C}$ in July. It decreases towards the north. The annual precipitation ranges from 100 to $1000 \mathrm{~mm}$ annually (Issa et al., 2013). 
Table 3. The constructed dams and barrage within the SARB

\begin{tabular}{|c|c|c|c|c|c|c|}
\hline Country & Name of dam & River & $\begin{array}{l}\text { Capacity } \\
\text { Storage } \mathrm{km}^{3}\end{array}$ & $\begin{array}{l}\text { Water surface } \\
\text { area km² }\end{array}$ & $\begin{array}{l}\text { Date of } \\
\text { operation }\end{array}$ & Use * \\
\hline \multirow[t]{11}{*}{ Turkey } & Devegecidi & Tigris & 0.2 & 32.1 & 1972 & I \\
\hline & Goksu & Tigris & 0.06 & 3.9 & 1991 & I \\
\hline & Dicle & Tigris & 0.60 & 24 & 1997 & HP,I \\
\hline & Kralkizi & Tigris & 1.92 & 57.5 & 1997 & $\mathrm{HP}$ \\
\hline & Batman & Tigris & 1.18 & 49.2 & 1998 & HP, I \\
\hline & Ilisu & Tigris & 10.41 & 299.5 & UC & HP \\
\hline & Keban & Euphrates & 31 & 675 & 1975 & HP \\
\hline & Karakaya & Euphrates & 9.58 & 268 & 1987 & HP \\
\hline & Ataturk & Euphrates & 48.7 & 817 & 1992 & HP, I \\
\hline & Karkamis & Euphrates & 0.16 & 28.4 & 1999 & $\mathrm{HP}, \mathrm{FC}$ \\
\hline & Birecik & Euphrates & 1.22 & 56.3 & 2000 & HP, I \\
\hline \multirow[t]{3}{*}{ Syria } & Tabaqa & Euphrates & 11.7 & 610 & 1975 & $\mathrm{HP}, \mathrm{I}$ \\
\hline & Baath & Euphrates & 0.09 & 27.2 & 1988 & $\mathrm{HP}, \mathrm{I}, \mathrm{FC}$ \\
\hline & Tishrine & Euphrates & 1.9 & 166 & 1999 & $\mathrm{HP}$ \\
\hline \multirow[t]{6}{*}{ Iran } & Dez & Karun & 3.46 & - & 1962 & HP, I \\
\hline & Karun & Karun & 3.14 & 54.8 & 1977 & HP, I \\
\hline & Marun & Karkheh & 1.2 & 25 & 1998 & HP, I \\
\hline & Karkheh & Karkheh & 7.8 & & 2001 & HP, I, FC \\
\hline & Karun-2 & Karun & 2.75 & & 2001 & $\mathrm{HP}$ \\
\hline & Karun-3 & Karun & 2.97 & & 2004 & I, H \\
\hline \multirow[t]{13}{*}{ Iraq } & Al-Kut ${ }^{*}$ & Tigris & & & 1939 & FD \\
\hline & Samarra & Tigris & 72.8 & 2170 & 1956 & FD, I, HP \\
\hline & Dokan & Tigris & 6.8 & 270 & 1959 & HP,I \\
\hline & Derbendikhan & Tigris & 3 & 114 & 1961 & I \\
\hline & Hamrin & Tigris & 3.56 & 450 & 1981 & $\mathrm{I}, \mathrm{FC}$ \\
\hline & Mosul & Tigris & 11.1 & 280 & 1986 & $\mathrm{HP}, \mathrm{I}, \mathrm{FC}$ \\
\hline & Al-Adheem & Tigris & 1.5 & - & 1999 & HP,I \\
\hline & Al-Amarah * & Tigris & - & - & 2001 & FD \\
\hline & Al Hindiyah & Euphrates & - & - & 1918 & FD \\
\hline & Raazza & Euphrates & 26 & 1810 & 1951 & $\mathrm{FC}$ \\
\hline & Habbaniyah & Euphrates & 3.3 & 426 & 1956 & FC \\
\hline & Haditha & Euphrates & 8.2 & 500 & 1984 & HP, I \\
\hline & Fallujah * & Euphrates & - & & 1985 & I \\
\hline
\end{tabular}

Note. HP: hydropower; I: irrigation; FC: flood control; FD: flow diversion; UC: under construction.

* Barrage.

Sources:

1(UNEP, 2001)

2(FAO, 2009)

The mean temperature in the headwaters for the $1941-2007$ climatic periods is about $13^{\circ} \mathrm{C}$, and annual mean precipitation for the same climatic periods is about $643 \mathrm{~mm}$. Approximately, $70 \%$ of the total precipitation fall during the period between October and April (Republic of Turkey, 2009).

The Middle East is one of the most affected regions by the global climate change. It will suffer from warm and dry conditions at the end of the 21 st century (Bozkurt \& Sen, 2013). Climate change in this region results in greater water scarcity, as rainfall decreases to $25 \%$ (regionally) and up to $40 \%$ (locally) (UNWWAP, 2009). The temperature has an increasing trend of $0.64^{\circ} \mathrm{C} / 100$ years (Republic of Turkey, 2009). The Evaporation also increases but the increase is small, its maximum rate is about 9\% (Terink et al., 2013; Bozkurt \& Sen, 2013) the average increase is around $0.23 \%$ per year. Consequently, there will be a reduction of $10-30 \%$ in the annual surface runoff from the headwaters regions by the year 2050 (Milly et al., 2005), with an average that decreases is about $0.5 \%$ per year. 


\subsection{Water Availability within the SARB}

The total potential flow of the Tigris River reduction and water demand increase with time. Annual mean of water flow amount is $43.00 \mathrm{~km}^{3} / \mathrm{yr}$, whereas the total water withdraw at the basin is $24.56 \mathrm{~km}^{3} / \mathrm{yr}$, so there are water surpluses of $18.44 \mathrm{~km}^{3} / \mathrm{yr}$ (Table 4), it can reach the SAR. A water of the river will decrease to 35.19 $\mathrm{km}^{3} / \mathrm{yr}$ by 2040 , in contrast water demand could climb up to $41.69 \mathrm{~km}^{3} / \mathrm{yr}$, and the water balance will be in deficits of $6.50 \mathrm{~km}^{3}$.

In 2030, the water balance of the Euphrates River will be negative, with a mean deficit of $4.58 \mathrm{~km}^{3} / \mathrm{yr}$ (Table 5). Due to decline in the discharge water to $28.14 \mathrm{~km}^{3} / \mathrm{yr}$ and increase of the water consumption to about 32.72 $\mathrm{km}^{3} / \mathrm{yr}$. Furthermore, the water deficit in that river could increase to $14.30 \mathrm{~km}^{3} / \mathrm{yr}$ in 2040 . The reduction rate of water flow in the Euphrates River is $0.5665 \mathrm{~km}^{3} / \mathrm{yr}$.

Due to decreased water flow in the Tigris and Euphrates Rivers, the water salinity of the two rivers is increasing in place and time (Abdullah, 2016).

Water demand within the Karkheh and Karun Rivers basins is increasing to $4.19 \mathrm{~km}^{3} / \mathrm{yr}$ and $7.08 \mathrm{~km}^{3} / \mathrm{yr}$ respectively by 2040 ; in contrast the water discharge in both rivers is decreasing to $4.75 \mathrm{~km}^{3} / \mathrm{yr}$ and $20.05 \mathrm{~km}^{3} / \mathrm{yr}$. However, the water balances in two rivers are surplus of $0.24 \mathrm{~km}^{3} / \mathrm{yr}$ and $12.57 \mathrm{~km}^{3} / \mathrm{yr}$ respectively (Table 6).

Table 4. Potential water use in the Tigris River basin $\left(\mathrm{km}^{3} / \mathrm{yr}\right)$

\begin{tabular}{llllllllll}
\hline Year & Country & AW & P $(\mathrm{m})$ & PWD & IA (ha) & IWD & Eva. & TC & Balance \\
\hline 2000 & Turkey & 21.93 & 3.05 & 0.28 & 57,000 & 0.63 & 0.63 & 1.54 & +20.39 \\
& Iran & 4.30 & 0 & 0 & 0 & 0 & 0 & 0 & +4.30 \\
& Iraq & 16.77 & 14.10 & 1.80 & $1,166,880$ & 16.34 & $4.88^{2}$ & 23.02 & +18.44 \\
& Total & 43.00 & 17.15 & 2.08 & $1,223,880$ & 16.97 & 5.51 & 24.56 & +18.44 \\
2010 & Turkey & 20.86 & 3.47 & 0.32 & 99,226 & 1.09 & 0.65 & 2.06 & +18.80 \\
& Iran & 4.09 & 0 & 0 & 0 & 0 & 0 & 0 & +4.09 \\
& Iraq & 15.95 & 18.4 & 2.36 & $1,282,595$ & 17.96 & 4.99 & 27.37 & +11.47 \\
& Total & 40.90 & 21.87 & 2.68 & $1,381,821$ & 19.05 & 5.64 & 29.43 & +11.47 \\
2020 & Turkey & 19.84 & 3.95 & 0.36 & 172,733 & 1.90 & 0.67 & 2.93 & +16.91 \\
& Iran & 3.89 & 0 & 0 & 0 & 0 & 0 & 0 & +3.89 \\
& Iraq & 15.17 & 24.02 & 3.07 & $1,409,785$ & 19.74 & 5.11 & 28.13 & +7.84 \\
& Total & 38.90 & 27.97 & 3.43 & $1,582,518$ & 21.64 & 5.78 & 31.06 & +7.84 \\
2030 & Turkey & 18.87 & 4.49 & 0.41 & 300,694 & 3.31 & 0.69 & 4.41 & +14.46 \\
& Iran & 3.70 & 0 & 0 & 0 & 0 & 0 & 0 & +3.70 \\
& Iraq & 14.43 & 31.35 & 4.01 & $1,549,588$ & 21.69 & 5.23 & 30.93 & +1.66 \\
& Total & 37.00 & 35.84 & 4.42 & $1,850,282$ & 25.00 & 5.92 & 35.34 & +1.66 \\
2040 & Turkey & 17.95 & 5.11 & 0.47 & 540,000 & 5.94 & 0.71 & 7.12 & +10.83 \\
& Iran & 3.52 & 0 & 0 & 0 & 0 & 0 & 0 & +3.52 \\
& Iraq & 13.72 & 41.92 & 5.37 & $1,703,253$ & 23.85 & 5.35 & 34.57 & -6.50 \\
& Total & 35.19 & 47.03 & 5.84 & $2,243,253$ & 29.79 & 6.06 & 41.69 & -6.50 \\
\hline
\end{tabular}

Note. AW: Available water; TC: Total consumption.

Sources:

1(Beaumout, 1998)

2(Ohara et al., 2011)

Table 5. Potential water use in the Euphrates River basin $\left(\mathrm{km}^{3} / \mathrm{yr}\right)$

\begin{tabular}{llllllllll}
\hline Year & Country & AW & P $(\mathrm{m})$ & PWD & IA (ha) & IWD & Eva. & TC & balance \\
\hline 2000 & Turkey & 29.12 & 6.28 & 0.57 & 103,000 & 1.13 & $1.10^{1}$ & 2.8 & +26.32 \\
& Syria & 3.60 & 4.45 & 0.57 & 240,000 & 2.64 & $1.45^{2}$ & 4.66 & +25.26 \\
& Iraq & 0 & 7.81 & 1.00 & 549,120 & 7.67 & $3.62^{2}$ & 12.29 & +12.97 \\
& Total & 32.72 & 18.54 & 2.14 & 892,120 & 11.44 & 6.17 & 19.75 & +12.97 \\
2010 & Turkey & 27.70 & 7.15 & 0.65 & 179,303 & 1.97 & 1.12 & 3.74 & +23.96 \\
& Syria & 3.42 & 5.69 & 0.73 & 310,080 & 3.4 & 1.48 & 5.61 & +21.77 \\
& Iraq & 0 & 10.2 & 1.31 & 603,574 & 8.45 & 3.70 & 13.46 & +8.31
\end{tabular}




\begin{tabular}{llllllllll}
\multirow{2}{*}{2020} & Total & 31.12 & 23.04 & 2.69 & $1,092,957$ & 13.82 & 6.30 & 22.81 & +8.31 \\
& Turkey & 26.35 & 8.14 & 0.74 & 312,131 & 3.43 & 1.15 & 5.32 & +21.03 \\
& Syria & 3.25 & 7.28 & 0.93 & 400,623 & 4.41 & 1.52 & 6.86 & +17.42 \\
& Iraq & 0 & 13.31 & 1.70 & 663,428 & 9.29 & 3.78 & 14.77 & +2.65 \\
& Total & 29.60 & 28.73 & 3.37 & $1,376,182$ & 17.13 & 6.45 & 26.95 & +2.65 \\
2030 & Turkey & 25.05 & 9.26 & 0.84 & 543,359 & 5.98 & 1.17 & 7.99 & +17.06 \\
& Syria & 3.09 & 9.32 & 1.19 & 517,605 & 5.69 & 1.55 & 8.43 & +11.72 \\
& Iraq & 0 & 17.37 & 2.22 & 729,217 & 10.21 & 3.87 & 16.3 & -4.58 \\
& Total & 28.14 & 35.95 & 4.25 & $1,790,181$ & 21.88 & 6.59 & 32.72 & -4.58 \\
2040 & Turkey & 23.83 & 10.54 & 0.96 & 910,000 & 10.70 & 1.20 & 12.86 & +10.97 \\
& Syria & 2.95 & 11.93 & 1.53 & 640,000 & 7.04 & 1.58 & 10.15 & +3.77 \\
& Iraq & 0 & 22.67 & 2.90 & 801,531 & 11.22 & 3.95 & 18.07 & -14.30 \\
& Total & 26.78 & 45.14 & 5.39 & $2,351,531$ & 28.96 & 6.73 & 41.08 & -14.30 \\
\hline
\end{tabular}

Sources:

1(Beaumout, 1998)

2(Ohara et al., 2011)

Table 6. Potential water use in the Karkheh and the karun Rivers basins $\left(\mathrm{km}^{3} / \mathrm{yr}\right)$

\begin{tabular}{llllllllll}
\hline Year & River & WA & P $(\mathrm{m})$ & PWD & IA (ha) & IWD & Eva. & TC & Balance \\
\hline 2000 & Kharkeh & 5.80 & 3.48 & 0.32 & 93,900 & 1.03 & $1.07^{1}$ & 2.42 & +3.38 \\
& Karun & 24.50 & 3.05 & 0.28 & 280,000 & 3.08 & $1.2^{1}$ & 4.56 & +19.94 \\
& Total & 30.30 & 6.53 & 0.6 & 373,900 & 4.11 & 2.27 & 6.98 & +19.94 \\
2010 & Kharkeh & 5.51 & 4.00 & 0.37 & 116,718 & 1.28 & 1.09 & 2.74 & +2.77 \\
& Karun & 23.30 & 3.50 & 0.32 & 348,040 & 3.83 & 1.23 & 5.38 & +17.92 \\
& Total & 28.81 & 7.5 & 0.69 & 464,758 & 5.11 & 2.32 & 8.12 & +20.69 \\
2020 & Kharkeh & 5.25 & 4.60 & 0.42 & 145,080 & 1.60 & 1.12 & 3.14 & +2.11 \\
& Karun & 22.16 & 4.02 & 0.37 & 432,614 & 4.76 & 1.26 & 6.39 & +15.77 \\
& Total & 27.41 & 8.62 & 0.79 & 577,694 & 6.36 & 2.38 & 9.53 & +15.88 \\
2030 & Kharkeh & 4.99 & 5.29 & 0.48 & 180,335 & 1.98 & 1.14 & 3.60 & +1.39 \\
& Karun & 21.08 & 4.62 & 0.42 & 480,000 & 5.28 & 1.29 & 6.99 & +14.09 \\
& Total & 26.07 & 9.91 & 0.9 & 660,335 & 7.26 & 2.43 & 10.59 & +15.48 \\
2040 & Kharkeh & 4.75 & 6.07 & 0.55 & 224,156 & 2.47 & 1.17 & 4.19 & +0.56 \\
& Karun & 20.05 & 5.31 & 0.48 & 480,000 & 5.28 & 1.32 & 7.08 & +12.97 \\
& Total & 24.80 & 11.38 & 1.03 & 704,156 & 7.75 & 2.49 & 11.87 & +13.53 \\
\hline
\end{tabular}

Source:

1(Ohara et al., 2011)

\subsection{Water Demand of the SARB}

Most of water in the SARB is used for agricultural irrigation, domestic purposes and limited industrial activity. Although water demands among the basin's countries vary, the Agriculture field is the largest water consuming for each country. The average of irrigation water needs represented about $87.62 \%$, while domestic use about $7.35 \%$ (Table 7). Therefore, the agricultural and domestic demands have around $95 \%$ of the total water withdrawal in that basin. Irrigation water requirements of Syria are $94.4 \%$ of water use in comparison with domestic and industrial uses form $3.7 \%$ and $1.9 \%$ respectively. In Turkey Irrigation water demands represent $72.5 \%$ of total water use, while domestic and industrial forms $16.4 \%$ and $11.1 \%$ respectively.

In 2000, the overall estimation of the total water demand in the SARB is $51.29 \mathrm{~km}^{3} / \mathrm{yr}$, the average annual water inflow was $106.02 \mathrm{~km}^{3} / \mathrm{yr}$. Hence, the water balance was $+54.73 \mathrm{~km}^{3} / \mathrm{yr}$ (Table 8 ). The water demand will be expected to increase to $94.64 \mathrm{~km}^{3} / \mathrm{yr}$ during 2040 due to agricultural development and population growth, whereas water flow will decrease to $86.77 \mathrm{~km}^{3} / \mathrm{yr}$ because of climate warming. This case will lead to deficit of the water balance of about $7.87 \mathrm{~km}^{3} / \mathrm{yr}$. 
Table 7. Percentage of water Consumption by main sectors within countries of SRB

Source:

\begin{tabular}{llll}
\hline & & \multicolumn{2}{c}{ Water withdrawal } \\
\cline { 3 - 3 } Country & agricultural purposes $\%$ & domestic supplies \% & industrial use \% \\
\hline Turey & 72.5 & 16.4 & 11.1 \\
Syria & 94.4 & 3.7 & 1.9 \\
Iraq & 92 & 3 & 5 \\
Iran & 91.6 & 6.3 & 2.1 \\
Mean & 87.62 & 7.35 & 5.03 \\
\hline
\end{tabular}

(Kangarani, 2006)

Table 8 . Water balance $\left(\mathrm{km}^{3} / \mathrm{yr}\right)$ of whole river basin

\begin{tabular}{llll}
\hline Year & Total water available & Total conception & Water balance \\
\hline 2000 & 106.02 & 51.29 & +54.73 \\
2010 & 100.83 & 60.36 & +40.47 \\
2020 & 95.91 & 67.54 & +28.37 \\
2030 & 91.21 & 78.65 & +12.56 \\
2040 & 86.77 & 94.64 & -7.87 \\
\hline
\end{tabular}

\subsection{Freshwater discharge in the SAR}

The mean annual flow of the SAR at Basrah and Mehilla sites during 1977-1978 year was $919 \mathrm{~m}^{3} / \mathrm{s}(28.95$ $\left.\mathrm{km}^{3} / \mathrm{yr}\right)$. This increased to $1189 \mathrm{~m}^{3} / \mathrm{s}\left(37.45 \mathrm{~km}^{3} / \mathrm{yr}\right)$ at Seebah and Fao sites due to the water received from the Karun River (Table 9). In 1994- 1995 year the average annual discharge decreased to $724 \mathrm{~m}^{3} / \mathrm{s}\left(22.81 \mathrm{~km}^{3} / \mathrm{yr}\right)$ and $815 \mathrm{~m}^{3} / \mathrm{s}\left(25.67 \mathrm{~km}^{3} / \mathrm{yr}\right)$ upstream and downstream Karun River respectively. The mean monthly discharge gradually increases from January to July. The greatest flow occurred in June and May for the 1978-1979, with an average of $1506 \mathrm{~m}^{3} / \mathrm{s}$ and $2465 \mathrm{~m}^{3} / \mathrm{s}$ upstream and downstream respectively. In 1994-1995 the maximum flow occurred in April and February. The average values at Basrah and Fao were $900 \mathrm{~m}^{3} / \mathrm{s}$ and $2465 \mathrm{~m}^{3} / \mathrm{s}$ respectively.

Table 9. Monthly average of water discharge $\left(\mathrm{m}^{3} / \mathrm{s}\right)$ in the SAR at four sites

\begin{tabular}{|c|c|c|c|c|c|c|c|c|c|c|c|c|c|c|}
\hline \multicolumn{15}{|c|}{ Months } \\
\hline Year & Site & Oct. & Nov & Des & Jan. & Feb. & Mar. & Apr. & May. & Jun. & Jul. & Aug & Sep. & Av. \\
\hline \multirow[t]{2}{*}{$77-1978^{1}$} & $\mathrm{~A}$ & 230 & 317 & 495 & 797 & 916 & 1082 & 1191 & 1313 & 1506 & 1463 & 963 & 563 & 919 \\
\hline & B & 230 & 317 & 495 & 797 & 916 & 1082 & 1191 & 1313 & 1506 & 1463 & 963 & 563 & 919 \\
\hline \multirow[t]{2}{*}{$48-1960^{2}$} & $\mathrm{C}$ & 392 & 449 & 565 & 753 & 1021 & 1515 & 2111 & 2465 & 2270 & 1456 & 785 & 486 & 1189 \\
\hline & $\mathrm{D}$ & 392 & 449 & 565 & 753 & 1021 & 1515 & 2111 & 2465 & 2270 & 1456 & 785 & 486 & 1189 \\
\hline \multirow[t]{4}{*}{$94-1995^{3}$} & $\mathrm{~A}$ & 632 & 616 & 600 & 831 & 891 & 895 & 900 & 729 & 686 & 678 & 612 & 615 & 724 \\
\hline & B & 632 & 616 & 600 & 831 & 891 & 895 & 900 & 729 & 686 & 678 & 612 & 615 & 724 \\
\hline & $\mathrm{C}$ & 834 & 879 & - & 1039 & 1064 & - & 725 & 547 & - & 601 & 826 & - & 815 \\
\hline & D & 834 & 879 & - & 1039 & 1064 & - & 725 & 547 & - & 601 & 826 & - & 815 \\
\hline \multirow[t]{4}{*}{$10-2011^{3}$} & A & 39 & 36 & 35 & 39 & 51 & 45 & 38 & 50 & 43 & 42 & 45 & 62 & 44 \\
\hline & B & 39 & 36 & 35 & 39 & 51 & 45 & 38 & 50 & 43 & 42 & 45 & 62 & 44 \\
\hline & $\mathrm{C}$ & 39 & 36 & 35 & 39 & 51 & 45 & 38 & 50 & 43 & 42 & 45 & 62 & 44 \\
\hline & D & 39 & 36 & 35 & 39 & 51 & 45 & 38 & 50 & 43 & 42 & 45 & 62 & 44 \\
\hline
\end{tabular}

Note. A: Basrah; B: Mehilla; C: Seebah; D: Fao.

Sources:

1 (Ministry of Irrigation, 1979)

2 (Al- Mahdi \& Salman, 1997)

3 (Al-Asadi et al., 2015) 
In 2010 the hydrological regime of the SAR discharge was almost completely dependent on the freshwater influx from the Tigris River as a result of diverting flow of the Karkhah and Karun Rivers inside the Iranian boundaries and cutoff the Euphrates River. Therefore, the mean annual discharge of the SAR dropped to $44 \mathrm{~m}^{3} / \mathrm{s}(1.39$ $\mathrm{km}^{3} / \mathrm{yr}$ ), with a monthly variation limited, it's from $35 \mathrm{~m}^{3} / \mathrm{s}$ and $62 \mathrm{~m}^{3} / \mathrm{s}$.

\subsection{Water quality of the SAR}

Water quality of the SAR is influenced by the chemical ions inflow from the main tributaries of the River and the marine salt from Persian Gulf (Moyel \& Hussain, 2015; Abdullah, 2016). The mean TDS concentration at Basrah site for the 1977-1978 year was 0.71 g/l, increasing to $1.25 \mathrm{~g} / \mathrm{l}$ at Fao site (Table 10). In 1997-1998 year the average of TDS values increased to $0.96 \mathrm{~g} / \mathrm{l}$ at Basrah and $1.84 \mathrm{~g} / \mathrm{l}$ at Fao in 1994-1995. Due to the loss of most tributaries the freshwater flow in the river was reduced during 2010-2011 year combined with increases of the seawater intrusion from Persian Gulf, thus the mean TDS values high increase to $1.77 \mathrm{~g} / \mathrm{l}$ at Basrah, $2.30 \mathrm{~g} / \mathrm{l}$ at Mehilla site, $2.27 \mathrm{~g} / \mathrm{l}$ at Seebah site and the maximum TDS value of $12.21 \mathrm{~g} / \mathrm{l}$ at the Fao.

Table 10. Average monthly of TDS $(\mathrm{g} / \mathrm{l})$ in the SAR at four sites

\begin{tabular}{|c|c|c|c|c|c|c|c|c|c|c|c|c|c|c|}
\hline \multicolumn{15}{|c|}{ Months } \\
\hline Year & Site & Oct. & Nov & Des & Jan. & Feb. & Mar. & Apr. & May. & Jun. & Jul. & Aug & Sep. & Av. \\
\hline \multirow[t]{4}{*}{$77-1978^{1}$} & A & 1.1 & 1.0 & 0.8 & 0.6 & 0.5 & 0.6 & 0.5 & 0.7 & 0.4 & 0.4 & 0.7 & 1.2 & 0.71 \\
\hline & B & 0.63 & 0.65 & 0.89 & 0.94 & 0.80 & 0.83 & 0.78 & 0.88 & - & - & - & 0.85 & 0.81 \\
\hline & $\mathrm{C}$ & 0.48 & 1.14 & 1.15 & 0.92 & 0.58 & 0.42 & 0.31 & 0.71 & 0.35 & 0.55 & 1.94 & 0.26 & 0.73 \\
\hline & $\mathrm{D}^{2}$ & 0.98 & 1.62 & 1.70 & - & 0.89 & 1.12 & - & 1.16 & 0.78 & 0.94 & 2.20 & 1.15 & 1.25 \\
\hline \multirow[t]{2}{*}{$97-1998^{3}$} & A & 1.44 & 1.35 & 1.17 & 1.00 & 1.01 & 1.06 & 1.08 & 0.73 & 0.87 & 0.89 & - & 0.29 & 0.96 \\
\hline & B & 1.44 & 1.36 & - & 0.99 & 1.07 & 1.08 & 1.05 & 0.71 & 0.88 & 1.01 & 1.02 & - & 1.06 \\
\hline \multirow[t]{2}{*}{$94-1995^{3}$} & $\mathrm{C}$ & 1.36 & 0.94 & - & 0.90 & 0.83 & - & 0.95 & 0.96 & - & 1.10 & 1.47 & - & 1.07 \\
\hline & $\mathrm{D}$ & 1.27 & 0.83 & - & 0.96 & 0.94 & - & 1.08 & 0.97 & - & 2.68 & 5.99 & - & 1.84 \\
\hline \multirow[t]{4}{*}{$10-2011^{3}$} & A & 1.59 & 1.94 & 1.82 & 1.58 & 1.70 & 1.89 & 2.01 & 1.89 & 1.55 & 1.80 & - & 1.65 & 1.77 \\
\hline & B & - & 1.70 & 2.00 & 2.07 & 2.43 & 2.29 & 2.45 & 2.39 & - & - & 2.93 & 2.46 & 2.30 \\
\hline & $\mathrm{C}$ & 2.42 & 1.81 & 1.93 & 1.77 & 2.75 & - & 1.51 & 1.19 & 1.83 & 1.40 & 3.05 & 5.27 & 2.27 \\
\hline & D & 9.74 & 13.39 & 12.85 & 17.12 & - & 9.40 & 8.36 & 16.75 & 8.65 & 11.45 & 26.61 & 33.17 & 12.21 \\
\hline
\end{tabular}

Note. A: Basrah; B: Mehilla; C: Seebah; D: Fao.

Sources

1 (Hussin et al., 1991)

2 (Ministry of Water Resources, 1979)

3 (Al-Asadi et al., 2015)

\section{Discussion and Conclusions}

The SARB is a transboundary basin, as is comprised of two main tributaries, namely the Tigris and the Euphrates Rivers that originate in Turkey, in addition to the Karkheh and the Karun Rivers which originate in Iran. The potential of the total water flow in the whole basin is $106.02 \mathrm{~km}^{3} / \mathrm{yr}$, whereas the mean annual freshwater of the SAR during 1977-1978 water year was $37.45 \mathrm{~km}^{3} / \mathrm{yr}$. This represents about $35.37 \%$ of the total available water of the basin. The Tigris and the Euphrates contribute to about $68.5 \%$ of the total freshwater of the SAR, 38.1\% from the Tigris and 30.4\% from the Euphrates. The Karkheh and the Karun Rivers contribute to $31.5 \%$ of the mean discharge, with $8.8 \%$ from the Karkheh and 30.4\% from the Karun. Hydrological regime of the SAR depends on freshwater from these four tributaries plus the progression of seawater by the tides from Persian Gulf.

In the past (until 2000), the SAR used to receive freshwater from four main tributaries, with average about 37.5 $\mathrm{km}^{3} / \mathrm{yr}$. This quantity of freshwater could prevent the progress of seawater in the river and may reach a distance of about $5 \mathrm{~km}$ inside Persian Gulf (Massoud, 1978). Therefore, the annual mean of TDS concentration in the river water ranges from $0.71 \mathrm{~g} / \mathrm{l}$ at Basrah site to $1.25 \mathrm{~g} / \mathrm{l}$ at Fao site for the 1977-1978 water year.

The Present data indicate a shift toward water stress at the tributaries of the SAR in the future. Due to the increasing water demand as a result to growth of population and development of irrigated area, as well as the 
constructed dams within river basin. In addition to the contribution of climate warming in reduce water discharge, by reducing runoff and increasing water evaporation losses. This expected result will affect the amount of freshwater flowing in the Shatt Al-Arab channel.

The mean annual water discharge of the Tigris River will reduce to $35.19 \mathrm{~km}^{3} / \mathrm{yr}$ by 2040 , whereas the water withdraw increases to $41.69 \mathrm{~km}^{3} / \mathrm{yr}$, so the water balance will be in deficits of $6.50 \mathrm{~km}^{3}$. After entering Iraq, the reduction rate of water flow in the Tigris River is $0.26 \mathrm{~km}^{3} / \mathrm{yr}$, while this rate increases to $0.62 \mathrm{~km} / \mathrm{yr}$ at the confluence point (Qurna). This indicates that Iraq is the largest consuming country of water from this river.

In 2030, the water consumption of the Euphrates River will be about $32.72 \mathrm{~km}^{3} / \mathrm{yr}$, whereas the expected decline in the discharge water to $28.14 \mathrm{~km}^{3} / \mathrm{yr}$. Hence, the water balance deficit of $4.58 \mathrm{~km}^{3} / \mathrm{yr}$. The early deficit in the Euphrates River because of extensive water consumption in agricultural irrigated land and domestic uses, compared with the limited amount of water discharge, in addition great water loss by evaporation from reservoirs. The reduction rate of water flow in the Euphrates River is $0.5665 \mathrm{~km}^{3} / \mathrm{yr}$. SAR is losing freshwater from the Euphrates; as a result of the dike construction by Iraqi go vernment in 2010 on the river at Basra boundaries about $32 \mathrm{~km}$ west the confluence point. Hence, the SAR lost $30.4 \%$ of the total freshwater discharge.

It should be noted that in future the surface water shortage within Iraq, eventually lead to decrease irrigated area. Hence, it cannot be expected that the Tigris and Euphrates flow dries, but the quantity and quality water properties will be unavailable for usage to extreme water flow scarcity.

Though, Turkish developing their water supply projects within the Tigris and the Euphrates Rivers basins, the overall estimation of water demand is about $7.12 \mathrm{~km}^{3} / \mathrm{yr}$ and $10.97 \mathrm{~km}^{3} / \mathrm{yr}$ in 2040 at the two rivers respectively. These represent $20.23 \%$ and $40.96 \%$ of the available water $\left(35.19 \mathrm{~km}^{3} / \mathrm{yr}\right.$ and $\left.26.78 \mathrm{~km}^{3} / \mathrm{yr}\right)$ of the basins. While water withdrawals are increasing for Iraq into $34.57 \mathrm{~km}^{3} / \mathrm{yr}$ and $18.07 \mathrm{~km}^{3} / \mathrm{yr}$ in 2040 at the two rivers respectively, it represents $98.24 \%$ and $67.48 \%$ of the total water flow. Due to de velopment of agricultural land and lack of regulatory framework for efficient use of water supply (FAO, 2012). Therefore, Iraq will witness severe shortages in water resources, as a result of the location in the lower part of basin.

The future water balances in the Karkheh and the Karun Rivers are expected to be positive, with a mean surplus of $0.24 \mathrm{~km}^{3} / \mathrm{yr}$ and $12.57 \mathrm{~km}^{3} / \mathrm{yr}$ respectively. The SAR is not receiving flow from two rivers since 2001 and 2009 , as result of the diversion of these rivers by Iran. Hence, the SAR lost $31.5 \%$ of the total amount.

Currently, the sources of freshwater in the SAR were limited to the Tigris River, with an annual discharge of 1.39 $\mathrm{km}^{3} / \mathrm{yr}$ by Al-Amarah barrage, for that then the river became part of the Tigris and its basin. The freshwater discharge of the SAR dropped about $96.29 \%$ of the total discharge in the water year 1977-1978, this quantity of freshwater flow can't prevent of seawater progress to the north of Fao city. Thus, the mean TDS values in the river water were highly increased to $1.86 \mathrm{~g} / \mathrm{l}$ at Basrah, and the maximum TDS values occurred at the Fao site with average $12.21 \mathrm{~g} / \mathrm{l}$. This high values due to the freshwater flow in the river was reduced during 2010-2011 year, combined with increases of the seawater intrusion from Persian Gulf, especially at the Fao site. Besides, there was a loss of most river's tributaries, in particular the Karun River which was as a natural dam that blocks or delays the progression of marine waters.

When TDS value for categorizing waters method is used (Hiscock, 2005), the river water within upstream from Basrah to Fao is considered to be of brackish water, while the downstream section from Fao to Persian Gulf is considered to be of saline water (seawater). This water is almost similar to the marine water environment at the north part of Persian Gulf, with ranges of TDS from 21.5-37.6 g/l (Al-Mahdi et al., 2007), and it's unsuitable for different uses. This could be an indicator fact that the estuary area of the SAR is regression distance of about 30 $\mathrm{km}$ in the river from Ras Albisha to the northern Fao city.

In 2040, the freshwater from the Tigris River will not be available to the SAR, as a result to extensive upstream water developments. Accordingly, it is expected that the TDS concentration in the Shatt Al-Arab water will record the highest levels, and progress increase of the marine waters towards the north in the river channel to reach Basrah city. As it occurred in August 2009, the saline marine water intrusion reaches to Basrah city and increased TDS values to more than $15 \mathrm{~g} / \mathrm{l}$ as a result of decline freshwater discharge from the Tigris River to around $18 \mathrm{~m}^{3} / \mathrm{s}$. (Ministry of water resources, 2009).

According to the current changes expected, the Shatt Al-Arab channel will be just a waterway for marine waters flowing by tide phenomenon, or as drainage channel for the wastewater flowing from different uses in the watershed, especially in the part extended from the city of Basrah to Persian Gulf, with a length is about $110 \mathrm{~km}$. Therefore, some researchers called for the construction the barrage in the southern part of the Shatt Al-Arab channel to prevent the intrusion of marine waters in to the river. 


\section{Recommendations}

The study gives forward the following recommendations:

1- Reconsidering the areas irrigated by surface water, irrigation systems and crop plants within Iraq especially in Basrah province.

2- Search for new solution to avoid freshwater scarcity in the SAR by using desalination plants.

3- Dispense with an idea of a construction barrage on southern SAR, due to the fact that in the future marine waters may be the main source of water supply to the peoples.

\section{Acknowledgments}

We would like to thank Prof. Dr. Abdul Zahra AL- Hello, Department of Marine Chemistry, Marine Science Center, University of Basrah, and Assist. Prof. Dr. Alaa Al-Abadi, Department of Geology, College of Science, University of Basrah, for valuable and very interesting. Many thanks also for Prof. Dr. Ala' Oda, and Assist. Prof. Mahdi Alasadi, Department of English, College of Education for Human Sciences, University of Basrah for reviewing English language of this manuscript.

\section{References}

Abdullah, A. D. (2016). Modelling approaches to understand salinity variations in a highly dynamic tidal river, the case of the Shatt al-Arab River, dissertation of Delft University of Technology and of the Academic Board of the UNESCO-IHE, $186 \mathrm{p}$.

Abughlelesha, S. M., \& Lateh, H. B. (2013). A Review and Analysis of the Impact of Population Growth on Water Resources in Libya. World Applied Sciences Journal, 23, 965-971. https://doi.org/10.5829/idosi.wasj.2013.23.07.13102

Al-Ansari, N. A. (2013). Management of Water Resources in Iraq: Perspectives and Prognoses. Engineering, 5, 667-684. https://doi.org/10.4236/eng.2013.58080

Al-Ansari, N., Ali, A. A., \& Knutsson, S. (2014). Present Conditions and Future Challenges of Water Resources Problems in Iraq. Journal of Water Resource and Protection, 6, 1066-1098. https://doi.org/10.4236/jwarp.2014.612102

Al-Asadi, S. A. R. (2016). A study of pH values in the Shatt Al-Arab River (southern Iraq). International Journal of Marine Science, 29, 1-8. https://doi.org/10.5376/IJMS.2016.06.0026

Al-Asadi, S. A., Abdullah S. S., \& Al-Mahmood, H. Kh. (2015). Estimation of minimum amount of the net discharge in the Shatt Al- Arab River (south of Iraq). Journal of Adab Al-Basrah, 2, 285-314. (In Arabic)

Al-Mahdi, A. A., Abdullah, S.S., \& Hussian, N. A. (2007). Some features of the physical oceanography in Iraqi marine waters. Marina Mesopotamica, 22(2), 209-222.

Al-Mahdi, A., A., \& Salman, H. H. (1997). Some Hydrological characteristics of the Shatt Al-Arab River, south of Iraq. Marina Mesopotamica, 12, 63-74.

Al-Yamani, F. (2008). Importance of the freshwater influx from the Shatt-Al-Arab River on the Gulf marine environment. Protecting the Gulf's Marine Ecosystems from Pollution, springer, pp 207-222.

Aqrawi, A. A. M. (1995). Correction of Holocene sedimentation rates for mechanical compaction: the Tigris-Euphrates Delta, lower Mesopotamia, Marine and petroleum geology, 12(4), 409- 416. https://doi.org/10.1016/0264-8172(95)96903-4

Beaumont, P. (1998). Restructuring of Water Usage in the Tigris-Euphrates Basin: The Impact of Modern Water Management Policies. Yale School of Forestry and Environmental Studies, Bulletin Series, 103, 168-186.

Belloumi, M., \& Matoussi, S. M. (2009). Measuring agricultural productivity growth in MENA countries. Journal of Development and Agricultural Economics, 4, 103-113. Retrieved from http://www.academicjournals.org/JDAE

Biedler, M. (2004). Hydropolitics of the Tigris-Euphrates River basin with implications for the European Union. Centre Européen de Recherche Internationale et Stratégique (CERIS), Research Papers N 1, 44 P.

Bozkurt, D., \& Sen, O. L. (2013). Climate change impacts in the Euphrates-Tigris Basin based on different model and scenario simulations. Journal of Hydrology, 480, 149-161. https://doi.org/10.1016/j.jhydrol.2012.12.021

Droogers, P., Immerzeel, W., Terink, W., Hoogeveen, J., Bierkens, M., van Beek, L., \& Debele, B. (2012). Water 
resources trends in Middle East and North Africa towards 2050. Hydrology and Earth System Sciences, 16, 3101-3114. Retrieved from http://www.hydrol-earth-syst-sci.net/16/3101/2012/

El-Fadel, M., El-Sayegh,Y., Abou Ibrahim, A., Jamali, D., \& El-Fadl, K. (2002). The Euphrates- Tigris basin: A case study in surface water conflict resolution. Journal of Nat. Resour. Life Sci. Educ., 31, 99-110. Retrieved from http://www.JNRLSE.org

Food and Agriculture Organization (FAO). (2009). Irrigation in the Middle East region in figures: aquastat Survey-2008, FAO Water Reports 34. Edited by K. Frenken, Rome, 402 p.

Food and Agriculture Organization (FAO). (2012). Iraq: Agriculture sector note, FAO investment center, country highlights, Rome, 72p. Retrieved from http://www.fao.org

Haddad, G., SzéleS I., \& ZSarnóczaI, J. S. (2013). Water management development and agriculture in Syria, Bull. of the Szent István Univ., Gödöllö, 2008, Social Sciences, Szent István University, Gödöllö, Hungary, 183-194.

Hiscock, K. M. (2005). Hydrogeology Principles and Practice, Black Well Publishing, USA., 389 P.

Hussain, N. A., Al-Najar, H. H., Al-Saad, H. T., Yousif, U. H. and Al- Saboonchi, A. A. (1991). Shatt Al-Arab basic scientific studies, Marine Science Centre Publ. Basrah University., 391 p. (In Arabic).

Issa, E., Al-Ansari, N., Sherwany, G., \& Knutsson, S. (2014). Expected Future of Water Resources within Tigris-Euphrates Rivers Basin, Iraq. Journal of Water Resource and Protection, 6, 421-432. https://doi.org/10.4236/jwarp.2014.65042.

Issa, I., Al-Ansari, N., Sherwany, G. \& Knutsson, S. (2013). Trends and future challenges of water resources in the Tigris-Euphrates Rivers basin in Iraq. Hydrol. Earth Syst. Sci. Discuss., 10, 14617-14644. https://doi.org/10.5194/hessd-10-14617-2013

Jaradat, A. A. (2002). Agriculture in Iraq: Resources, Potentials, Constraints, and Research Needs and Priorities, NCSC Research Lab, ARS-USDA 803 Iowa Avenue, Morris, MN 56267, Submitted to: Department of State-Middle East Working Group on Agriculture Washington, D. C., USA, 83 P.

Jones, C., Sultan, M., Yan, E., Milewski, A., Hussein,M., Al-Dousari, A., Al-Kaisy, S., \& Becker, R. (2008). Hydrologic impacts of engineering projects on the Tigris-Euphrates system and its marshlands. Journal of Hydrology, 353, 59-75. https://doi.org/10.1016/j.jhydrol.2008.01.029

Kangarani, H. M. (2006). Euphrates and Tigris watershed Economic, social and institutional aspects of forest in an integrated watershed management, Forestry Outlook Study for West and Central Asia (FOWECA), Working paper, FAO, Rome, $73 \mathrm{p}$.

Marjanizadeh, S., Qureshi, A. S., Turral, H., \& Talebzadeh, P. (2009). From Mesopotamia to the third millennium: the historicaltrajectory of water development and use in the Karkheh River basin, Iran, International Water Management Institute (IWMI), working paper 135, 43 p. Retrieved from http://www.iwmi.org/Publications/Working_Papers/index.aspx

Massoud, A. H. S. (1978). Seasonal Variations of some PhysicoChemical Conditions of Shatt al-Arab Estuary, Iraq. Estuarine and Coastal Marine Science, 6, 503-513. 0302-3 24/78/0501-0Jj03 \$01.00/O @ Academic Press Inc. (London) Ltd.

Mavron, V. C. \& Phillips, T. N. (2000). Elements of mathematics for economics and finance, springer, UK, 311 P.

Milly, P. C. D., Dunne, K. A., \& Vecchia, A. V. (2005). Global pattern of trends in streamflow and water availability in a changing climate. Nature: International weekly journal of science, 438, 347-350. https://doi.org/10.1038/nature04312

Ministry of Irrigation. (1979). Shatt Al-Arab Project, Feas, Rep. Draft, Studies of Salinity Problem, Part A, Text, Polservies Co., Basrah, Iraq.

Ministry of Water Resources. (1979-2009). Directorate of Basra Water Resources, (Un published data).

Moyel, M. S., \& Hussain, N. A. (2015). Water quality assessment of the Shatt al-Arab River, Southern Iraq. Journal of Coastal Life Medicine, 3, 459-465. https://doi.org/ 10.12980/JCLM.3.2015J5-26

Ohara, N., Asce, A. M., Kavvas, M. L., Asce, F., Anderson, M. L., Asce, M., Richard Chen, Z. Q., Asce, M., \& Yoon, J. (2011). Water Balance Study for the Tigris-Euphrates River Basin. Journal of hydrologic engineering, 1071-1082. https://doi.org/10.1061/(ASCE)HE.1943-5584.0000209 
Patrick, M. (2004). Water security in the Middle East, growing conflict over development in the Euphrates-Tigris basin, Thesis, M.Phil International Peace Studies, Trinity College, Dublin, Ireland, 79 p.

Postel, S. L. (2000). Entering an era of water scarcity: the challenges ahead. Ecological Applications, 10, 941-948.

Republic of Turkey. (2009). Turkey Water Report, General Directorate of State Hydraulic Works, Turkey, 52 P.

Sadeghian, M. S., Hassunizadeh, H., \& McNaughton, A. N. (2003). Optimising the River Karun system, Iran. River Basin Management 11 Transactions on Ecology and the Environment, 60, 109- 118.

Terink, W., Immerzeel, W. W., \& Droogers, P. (2013). Climate change projections of precipitation and reference evapotranspiration for the Middle East and Northern Africa until 2050. international journal of climatology, https://doi.org/10.1002/joc.3650

The United Nations World Water Assessment Programme (UNWWAP). (2009). Climate Changes, Water Security and Possible Remedies for the Middle East, Scientific Paper, Jon Martin Trondalen, From Potential Conflict to Co-operation Potential, UNESCO-PCCP, 32 P.

U.S. Army War College (USAWC). (2001). The Euphrates-Tigris basin and the southeastern Anatolia project: Is armed conflict in the offing? Distribution statements approved for public release. Distribution is unlimited, $24 \mathrm{p}$.

United National Environment Programs (UNEP). (2001). The Mesopotamian Marshlands: Demise of an Ecosystem, Early Warning and Assessment Technical Report, 3, UNEP/DEWA/TR.01-3, UNEP, Geneva, $58 \mathrm{p}$.

United Nations (UN). (2001). Population Division, Department of Economic and Social Affairs, population. Environment and Development.

United Nations Economic and Social Commission for Western Asia (ESCWA). (2013). Inventory of shared water resources in western Asia, New York, $606 \mathrm{P}$.

Yildiz, D. (2016). Natural Diminishing Trend of the Tigris and Euphrates Stream flows is Alarming for the Middle East Future, World Scientific News, 47, 279-297.

\section{Copyrights}

Copyright for this article is retained by the author(s), with first publication rights granted to the journal.

This is an open-access article distributed under the terms and conditions of the Creative Commons Attribution license (http://creativecommons.org/licenses/by/4.0/). 